\title{
Study on the Development of Urban Community Pension Service Human Resources of Kunming City
}

\author{
Ma Keji \\ Yunnan University of Finance and Economics \\ School of Public Management \\ Kunming, Yunnan, P.R. China
}

\author{
Gao Yinchun \\ Yunnan University of Finance and Economics \\ School of Public Management \\ Kunming, Yunnan, P.R. China
}

\begin{abstract}
Facing the aging tendency in Kunming is more and more serious, the author pointed out the present situation of total human resources of urban community pension service is currently insufficient, the educational status quo is lower and so on, analysed the problems of existed human resources such as low professional recognition, low professional level etc., and then put forward the human resources development mechanism of attracting, exploiting and retaining talents.
\end{abstract}

Key Words-Urban Community; Pension Service; Human Resources

\section{INTRODUCTION}

According to the sixth national census released by the National Bureau of Statistics, as of November 1, 2010, the proportion of population above 60 has reached to $13.26 \%$. The over-60s aging population of Kunming has reached to 763,500, accounting for $14.45 \%$ of the total population of the city's household registration. It shows that aging population presents a trend of rapid development and large scale [1].Community pension. In the face of severe pension pressure, as a kind of non institutional endowment way is one of the effective way to deal with the aging of the population, and shows strong flexibility because it can take different ways of service according to different service objects. Community pension service can provide comprehensive service and support for the elderly on the aspects of daily life care, spiritual life, health care etc.

\section{Urban Community Pension Service Human Resources Status OF KUNMING}

\section{A. Total amount of personal and academic structure of pension service}

By 2015, there were 279 communities and 1535 full-time community staff in Kunming. Among them, 1016 people are high school and technical secondary school graduates accounted for $66.4 \%$ of workforce, 440 college graduates accounted for $28.7 \%$, bachelor degrees of 71 people accounted for $4.6 \%$, but only four people with graduate degrees accounted for $0.3 \%$, and the average age of them is 40.9 years old. On the basis of above data, the current Kunming city community service pension employees have following characteristics: 1.Educational level is lower. Most of these people are low-level educational persons, thus the highly educated personnel are inadequate, personnel quality is general low as well as age structure is older[2]. 2.Serious shortage personnel. There are only 1535 community workers in 279 communities. In the face of increasing aging population of Kunming City, the supply of community pension service staff showed a insufficient trend.

\section{B. Input formation of pension service personnel}

The main sources of urban community pension service human resources of Kunming.

Implement open recruitment. Relevant government and social departments recruit qualified community pension service workers in Kunming City through the ways such as Open recruitment, democratic election and competition for posts, as well as supplement these needed human resources to community pension service staff by "street agencies hire and citizens select".

Elect from neighborhood committee members. Through the way of regular election, including direct election, Community household representatives' election and so forth, to maintain community members' mobility and vitality.

Elect from college graduates. As a new force of community pension service, college graduates is an indispensable and important human resources to community pension service industry. In recent years, colleges and universities, which as the main bases training and providing professional talents, cultivate a number of high-quality community talents for Kunming city, provide high grade human resources for urban communities.

\section{Problems Existing IN THE COMMUNITY SERVICE FOR THE AGED}

\section{A. Low social recognition to the profession}

In 2004, the National Labor and Social Security Ministry revised the "National Occupation Standard of Social Workers", in which the professional status of social workers was nailed down. Although the state has promulgated the social occupation standard, the whole country is still in the stage of popularization. Additionally, there are many other relevant reasons result in the service objects can not satisfy the effect of working. It is not easy for residents to understand community pension service workers because they don't understand the identity establishment, and responsibilities of community pension service workers specifically. Therefore, these reasons are in large part lead to community pension service workers 
can not be accepted and recognized by various sections of society.

\section{B. Low degree of specialization}

Social work and management profession was listed as the university specialty setup by the National Department of Education in 1986, and in the following years it has developed rapidly. Colleges and universities in Kunming have set up the corresponding professional, and a large number of professional talents are cultivated for Kunming city every year. The curriculum of colleges value theory, but underestimate practice, which indirectly led to students' poor practical ability, a lack of relevant skills, and theoretical knowledge cannot be applied to practice, so their own service skills unable to meet community endowment service after joining the community jobs. In addition, many students do not want to engage in professional work, since they generally have the idea that engage in social grass-roots work as community pension service after graduation cannot reflect personal value. Though some of these workers chose this job at the beginning, most of them would leave every year. Due to a large number of full-time professional talents were lost, community endowment workers professional level couldn't be improved effectively and constantly. At the same time, the lack of appropriate policy support makes community pension service work unable to form its own professional talent team, and the lack of relevant professional positions seriously obstructs the development of community care services.

\section{Lower overall quality and insufficient professional personnel}

At present, community pension service workers in the front line are general only graduated from high school. The problem resulted from this situation is that these people lack of related professional knowledge and background such as specialized psychology, social science, community management, social work, gerontology etc. And most of these workers did not accept special training in the aspect of community pension service work, thus the professional theoretical knowledge and the actual work experience are both inadequate. At the same time, only a minority of college graduates with related majors chose to work in communities, and there are hardly professional ones. For these workers, it is difficult to develop their own professional talent team, adapt to the development of urban community endowment service industry and meet a variety of community residents demand for pension services.

\section{Heavy workload and weak sense of innovation}

Along with the rapid development of community construction and the change of need to contents and modes of community concept and community work in recent years, the new and higher requirements are put forward to community pension service workers. But community work is complicated and arduous, so community pension service workers struggle to cope with the daily work that slow to update knowledge, undervalue innovation consciousness and lack of dedicated spirit. Such a state is difficult to adapt to the needs of the development of community pension service industry, and is not conducive to the healthy development of community pension service workers.

\section{E. The lower-paid}

In recent years, Kunming City has adjusted the workers income for whole urban communities, such as to give some subsidies on the basis of the original, obtain 1000 - 1800 Yuan subsidy income according to the different jobs every month, and be able to apply for old-age, unemployment, medical insurance. But compared with the overall income level of Kunming City, community pension service workers' income is still lower.

\section{F. Unreasonable personnel structure and insufficient reserve personnel}

In Kunming, pension service personnel constitute is single and there is a fault presents in community pension service personnel because related professional graduates are not willing to work in the community. Finally, the further improvement of community service work for the elderly is prevented.

\section{Strategies to Deal With Supply of Community Pension Service HUMAN RESOURCES}

Community service human resource for the elderly is one of the most important and resources to develop the community care services industry. The development of community pension service human resource aims to provide high-quality human resources for the development of Kunming urban community endowment service industry, and one of the premises of the development of human resources is to have a sufficient quantity and quality human resources.

\section{A. "Abstract talents" mechanism to the workers}

\section{1) Improve the professional level and attract talents}

The professional development way of community pension service workers needs the government to establish and perfect the vocational qualification system and related laws and regulations of community pension service workers, and use the legal authority promote career development process of community endowment service workers[3].To attract community talents to participate in community endowment service works and promote the development of community pension service worker team by increasing the welfare, improving the living conditions of community pension service workers, and enhancing the attraction and social identity of community endowment service work.

2) Broaden the channels for introduction of talent, optimize the team structure

Government needs to improve community management system, introduces and trains professional personnel of community-based care service talents and provides more employment opportunities for them to promote the development of community pension service industry. To optimize knowledge structure and personnel structure of community care service workers by gradually innovating 
community talent introduction system, break the household registration and geographical restrictions of candidates and relax eligibility conditions to encourage the people with high level education, high work ability, and love community work, have innovative spirit as well as have rich experiences talents to participate in community pension service work. As a result, the Knowledge structure and personnel structure of community pension service work are optimized.

\section{B. Perfect " talent exploitation" mechanism of professional community endowment service worker}

\section{1) Reinforce specialization construction}

We need to provide an effective training to the existing community care service workers on relevant knowledge and skills by following ways: The first way is to take professional training in colleges and universities that have communitybased profession in Kunming. The second is the government provides training fund and communities themselves make their own arrangements to organize specialized training, and they can use alternate method of training considering the special nature of the work. Experts hired by the work of communitybased care services to the community for teaching, the use of regular and irregular combination of lectures, to explain the relevant theory and practical skills.

\section{2) Great efforts to train high-quality professional talent}

To promote sustained and effective development of community-based care services in Kunming through strengthening the cultivation of high-level personnel, selecting a number of powerful colleges and universities in Kunming and positively piloting the social work of doctors and masters. Furthermore, since the academic education in this way a long period of education, educational content system, students can learn deep expertise, but lack of practice, but also it is a lot of community-based care services through job training will combine theory with practice .

3) Improve community care service human resources development system

Government should develop guidance for community care service workers human resource development planning, train community care workers of professional services market, provide financial support for the establishment of community care service system of human resources development projects, improve community care service workers employment system, guide the community to establish job performance evaluation system, regulate training work of community care service workers.

\section{4) Establish a sound management system}

We need to develop a comprehensive job performance evaluation management system to regulate tracking, guidance, monitoring and evaluation of job performance community care service workers. The second is to develop a reasonable assessment and incentive management system. Only the pay and performance of community care service workers linked to the greatest degree stimulate community care service workers initiative.

\section{Strengthen community care service personnel, "leaving talent" mechanism}

Community care service development of human resources is not only to enhance the professional skills and service levels of community care service workers, and the more important thing is to retain talents, avoid brain drain can take the following measures:

- Reasonable job pay. Kunming city government should introduce appropriate community care service workers wage jobs guidance on job professional job evaluations, setting up the wage scale, and in reference to the status quo wages in other sectors of the premise, and ultimately establish a competitive wage jobs[4].

- Strengthen the protection mechanism. The establishment of a number of protection mechanisms, the corresponding disbursement of funds to support it, to remove the worries of community care service workers.

- Fair mechanisms for promotion. The establishment of a fair, reasonable and clear promotion mechanisms and corresponding standards for community-based care services for their staff to have a clear career plan, can see the future career prospects, so that it can continue to engage in the peace of mind of community care services.

In the community care services, pension services Human resource development is the key to the development of community-based care services. Community care service is mainly aimed at the elderly and diverse community, rich and useful variety of care services in order to achieve the objective of maximizing the interests of the elderly. However, the current in the primary care services in the community, still faces many problems, such as administrative management, service is not in place, lack of talent, waste of resources, services, technology and other issues behind, to a reasonable and effective solution to these problems, we need to give full play to the community the power of. Therefore, strengthening urban community care service human resources development is an important part of the current development of community care service industry.

\section{REFERENCE}

[1] Wang Ning. An analysis on the trend of population aging and the construction of the service system for the aged in Kunming [J]. new western, 2010, (06), 11

[2] Chen Tao, Xiao Yun. Barriers and Countermeasures of service personnel training for private pension institutions $[\mathrm{J}]$. research on social security, 2013 (03):54

[3] Yu Tao. Investigation and Countermeasures on the present situation of the aged service personnel -- Taking Zibo city as an example [J]. social science aspect, 2011 (O6):94 - 95.

[4] Chen Zhuoyi, Chen Weiran. Status quo and Countermeasures of the construction of nursing staff in China (J]. Changsha District Vocational Technical College School of science, 2009 (4):724.

[5] Van der Klaauw,W,Wolpin K.Social security and the retirement and savings behavior of low-income households [J],Journal of Econometrics.2008,(145). 
[6] Diamond,P,Orszag,P.Saving social security[J],Journal of Economic perspectives.2005,(19).

[7] Gustman,A,Steinmeier T.The social security early entitlement age in a structural model of retirement and wealth [J],Journal of Public Economic.2005, (59). 